Original Research Paper

\title{
Isolation and Characterization of Organophosphate Pesticides Degrading Bacteria from Contaminated Agricultural Soil
}

\author{
Soni Yadav, Sitansu Kumar Verma and Hotam Singh Chaudhary \\ Department of Biotechnology, Madhav Institute of Technology and Science, Gwalior, M.P.-474005, India
}

\section{Article history}

Received: 15-04-2015

Revised: 05-05-2015

Accepted: 02-06-2015

Corresponding Author: Hotam Singh Chaudhary Department of Biotechnology, Madhav Institute of

Technology and Science,

Gwalior, M.P.-474005, India

Tel: +91-9981203686

Email: hotamsingh $@$ gmail.com

\begin{abstract}
The soil sample was collected from Agriculture University Gwalior, Madhya Pradesh, India which is having a history of repeated pesticide application. Bacterium capable of degrading Malathion and Dichlorvos were isolated and identify as Staphylococcus sp. Micrococcus sp. Entrobacte sp. Bordetella sp. Pseudomonas sp. and Klebsella sp. The growth of all six pesticide degrading isolates was assessed in Mineral Salt Medium (MSM) canting $100 \mathrm{mg}$ /lit of each pesticide. The maximum growth rate by the isolates Pseudomonas sp. AUG12 were 1.564 and 1.435 for Malathion and Dichlorvos respectively after $140 \mathrm{~h}$ Plate assay revealed that Pseudomonas sp. AUG12 could grow with high concentration of Malathion (1900 mg/lit) and Dichlorvos (1500 mg/lit). The total protein concentration was higher in the supernatant of Pseudomonas sp. AUG12 extracellular fraction which is $97 \mu \mathrm{g} / \mathrm{mL}$ for Malathion and $99 \mu \mathrm{g} / \mathrm{mL}$ for Dichlorvos. The beast Pseudomonas sp. AUG12 was therefore used in further experiment. The maximum growth ret of Pseudomonas was recorded at $30^{\circ} \mathrm{C}$ and $\mathrm{pH} 7.0$ the growth of Pseudomonas was maximum in the presence of sucrose fallowed by starch maltose the least growth was recorded in lactose the growth of Pseudomonas sp. AUG12 was maximum in the presence of peptone fallowed by yeast extract and beef extract. The least growth was recorded in urea as nitrogen source. The result of this study suggested a relation among microbial growth $\mathrm{pH}$ and temperature in MSM medium with different carbon and nitrogen source. The Organophasphorus Phosphatase (OPP) production and that OPP concentration were higher in the supernatant of Pseudomonas sp. AUG12 extracellular fraction.
\end{abstract}

Keywords: Malathion, Dichlorvos, Pseudomonas sp. Pesticides, OPP

\section{Introduction}

Although some persistent pesticide have been banned from agricultural and public health use during the past few years. High concentration of pesticides has been contaminating in soil, water and sediment samples. Bioremediation is an environmental cleanup process that currently being investigated for use on a wide verity of chemical (Aruna et al., 2014). It is the use of natural occurring microorganism to enhance biodegradation to detoxify the contaminant. Pesticides are organic compounds manufactured and used control destructive pests such as insect, plant disease organism and weeds in agricultural field. The application of pesticides may cause adverse effect. Among the different from of life and among the ecosystem the quality of ground water soil in land and terrestrial water and air are all affected by pesticide contamination (Eddleston et al., 2008; Ahn et al., 2011).

The use of microbes in the bioremediation and detoxification of many toxic xenobiotics, especially toxic pesticide is an efficient tool for the remediation of contaminated sites in the environment (Jamaluddin et al., 2012). Many microorganisms that are able to degrade organophosphate pesticide have been isolated from soil around the world. Previous research have shown that pesticide Malathion, Chlorochlorpyrifose, Dichlorvos degrading bacteria applied as single strains or as consortia to increase the rate of degradation of pesticide Malathion, Chlorochlorpyrifose, Dichlorvos in soil (McCoy et al., 2012; Qi et al., 2012; Yonar et al., 2014). Organophosphate pesticide constitutes a group of widely used very heterogeneous compound that 
share a phosphoric acid derivative chemical structure (Basarslan et al., 2014; Hamer, 2010).

Degradation of pesticides is usually a combination of a number of processes, including microbial degradation and chemical hydrolysis and is also influenced by some physicochemical properties such as temperature, $\mathrm{pH}$ and carbon and nitrogen source (Gunther and Gunther, 1973). However, biodegradation is the primary mechanism of pesticide degradation and detoxification in soils. Thus bacteria and other microbes may have a major effect on the persistence of most organophosphate pesticides in soil (Surekha et al., 2008). Biodegradation is a common method for the removal (degradation and detoxification) of organophosphate pesticides because of its low cost and low collateral destruction of indigenous animal and plant organisms (Liu et al., 2007). Bacterial degradation is considered to be a major factor determining the fate of Malathion, Dichlorvos and other organophosphorus pesticide in the environment.

Malathion and Dichlorvos are belongs to organophosphate class of pesticide are most commonly used by farmers in India. Most synthetic organophosphate pesticides are highly toxic and are powerful inhibitors of acetylcholinesterase, an important enzyme involved in neurotransmission, in the form of acetylcholine substitutes (Goda et al., 2010; Singh et al., 2011). Environmental hazards and health risks caused by pesticides could therefore potentially affect human health and environment. So in situ degradation and detoxification of pesticides contaminated water and soils are very important (Chen et al., 2012).

The aim of the present study was to isolate and characterize new bacteria capable of degrading Malathion and Dichlorvos from agricultural soil. Many physicochemical parameters have been optimizing for the best growth of bacteria. Protein concentrations and OPP activity were also determined by various methods.

\section{Materials and Methods}

\section{Soil}

The soil sample used for the isolation of pesticide degrading bacteria were collected from a soya been field form agriculture University Gwalior. Triplicate soil sample were collected from the $5 \mathrm{~cm}$ to $10 \mathrm{~cm}$ layer. Soil sample were partially air dried and characterized. The properties of soil sample are listed in Table1.

\section{Pesticide}

Commercial grade Malathion (50\%), Dichlorvos (76\%) were procured from local pesticide shop from Gwalior, Madhya Pradesh. These pesticides belong to organophosphate class of pesticides and structures of pesticide are shown in Fig. 1.

\section{Chemicals}

The Mineral Salt Media (MSM) consist of $\left(\mathrm{g} \mathrm{L}^{-1}\right)$ $\mathrm{Na}_{2} \mathrm{HPO}_{4} 7 \mathrm{H}_{2} \mathrm{O}$ 3.6; $\left(\mathrm{NH}_{4}\right)_{2} \mathrm{SO}_{4} 1.0 ; \mathrm{KH}_{2} \mathrm{PO}_{4} 1.0 ; \mathrm{MgSO}_{4}$ $1.0 ; \mathrm{Fe}(\mathrm{NH})_{4}$ citrate $0.01 ; \mathrm{CaCl}_{2} .2 \mathrm{H}_{2} \mathrm{O} 0.1$ and $10 \mathrm{~mL}$ of trace element solution contained $\left(\mathrm{mg} \mathrm{L}^{-1}\right) \mathrm{ZnSO}_{4} \cdot 7 \mathrm{H}_{2} \mathrm{O}$ 10; Mncl2. $4 \mathrm{H}_{2} \mathrm{O}$ 3. CoCl. $6 \mathrm{H}_{2} \mathrm{O} \quad 1 ; \mathrm{NiCl}_{2} \quad 6 \mathrm{H}_{2} \mathrm{O} \quad 2$; $\mathrm{Na}_{2} \mathrm{MoO}_{4} .2 \mathrm{H}_{2} \mathrm{O} 3 ; \mathrm{H}_{3} \mathrm{BO} 3 ; \mathrm{H}_{3} \mathrm{BO}_{3} 30 ; \mathrm{Cucl}_{2} .2 \mathrm{H}_{2} \mathrm{O} 1$. The $\mathrm{pH}$ of the medium was adjusted to 7.0 (Cycon et al., 2009; Abo-Amer and Aly, 2011).

\section{Isolation of Pesticide Degrading Bacteria}

All the samples were used for isolation of pesticide degrading bacteria by enrichment culture technique using (MSM) supplemented with Sucrose 2.0, Yeast extract 3.0 containing each pesticide (Malathion, Dichlrovose) with the final pesticide concentration 100 $\mathrm{mg} / \mathrm{lit}$. The procedure to isolated bacteria consisted of the addition of $1.0 \mathrm{gm}$ of soil sample to a flask containing $100 \mathrm{~mL}$ of (MSM) medium with $100 \mathrm{mg} / \mathrm{lit}$ of each pesticide as a fungal inhibitor (Atit et al., 2013). The culture flasks were incubated on orbital shaker with $120 \mathrm{rpm}$ at $30^{\circ} \mathrm{C}$. Two $\mathrm{ml}$ cultures were then transfer to a fresh medium containing $100 \mathrm{mg} /$ pesticide and incubated. From fifth transfer $200 \mu \mathrm{L}$ were plated on nutrient agar medium and incubator for $24 \mathrm{~h}$ at $30^{\circ} \mathrm{C}$. The pure culture colonies bacteria stain were maintain by striking on nutrient agar slant and stored at $4{ }^{\circ} \mathrm{C}$ (Lederberg and Lederberg, 1952).

\section{Gram Reaction and Cell Morphology}

Grams staining of pure culture of all isolates were performing to study gram reaction and cell morphology. The isolates colonies color, transparency, shape and texture were observed directly.

\section{Biochemical Characterization}

The isolates were subjected to biochemical test included indole production, methyl red, citrate utilization, triple sugar iron, arginine hydrolysis, Voges Proskauer, casein utilization test and sugar fermentation test. Bergey's Manual of Determinative Bacteriology and 'PIBWIN' online software for bacteria identification were used as a reference to identify the isolates (Buchanan and Gibbons, 1984; Cowan, 1974).

\section{Plate Assay for Pesticides}

The maximum concentration of Malathion and Dichlorvos tolerated by the bacterial strains was determined by streaking the isolated strains on MSM agar plates containing various concentrations of each pesticide $100-2,000 \mathrm{mg} \mathrm{L}^{-1}$. All the plates were incubated for $30^{\circ} \mathrm{C}$ until visible growth was observed (Shafiani and Malik, 2003). 
Table 1. Characteristics of soil sample collected from Agriculture University, Gwalior

\begin{tabular}{lccccrr}
\hline Sample No. & Depth & $\mathrm{pH}$ & Moisture contain (\%) & Clay (\%) & Silt (\%) & Sand (\%) \\
\hline 1 & 10 & 7.3 & 4.71 & 65.0 & 8.16 & 26.8 \\
2 & 15 & 6.8 & 4.71 & 70.2 & 8.30 & 21.4 \\
3 & 10 & 6.9 & 7.54 & 69.1 & 6.80 & 24.0 \\
4 & 15 & 7.3 & 11.32 & 59.0 & 8.80 & 32.0 \\
5 & 10 & 6.3 & 7.54 & 54.0 & 10.80 & 3.00 \\
6 & 15 & 6.7 & 7.54 & 59.1 & 7.60 & 26.1 \\
7 & 10 & 6.5 & 7.66 & 63.3 & 10.30 & 29.0 \\
8 & 15 & 6.7 & 12.26 & 51.8 & 15.00 & 37.6 \\
9 & 10 & 6.8 & 20.75 & 60.0 & 14.60 & 25.0 \\
10 & 15 & 7.2 & 15.43 & 56.8 & 9.16 & 142.1 \\
11 & 10 & 7.1 & & 52.0 & 10.30 & 28.8 \\
12 & 15 & 7.3 & & 55.5 & & 34.1 \\
\hline
\end{tabular}

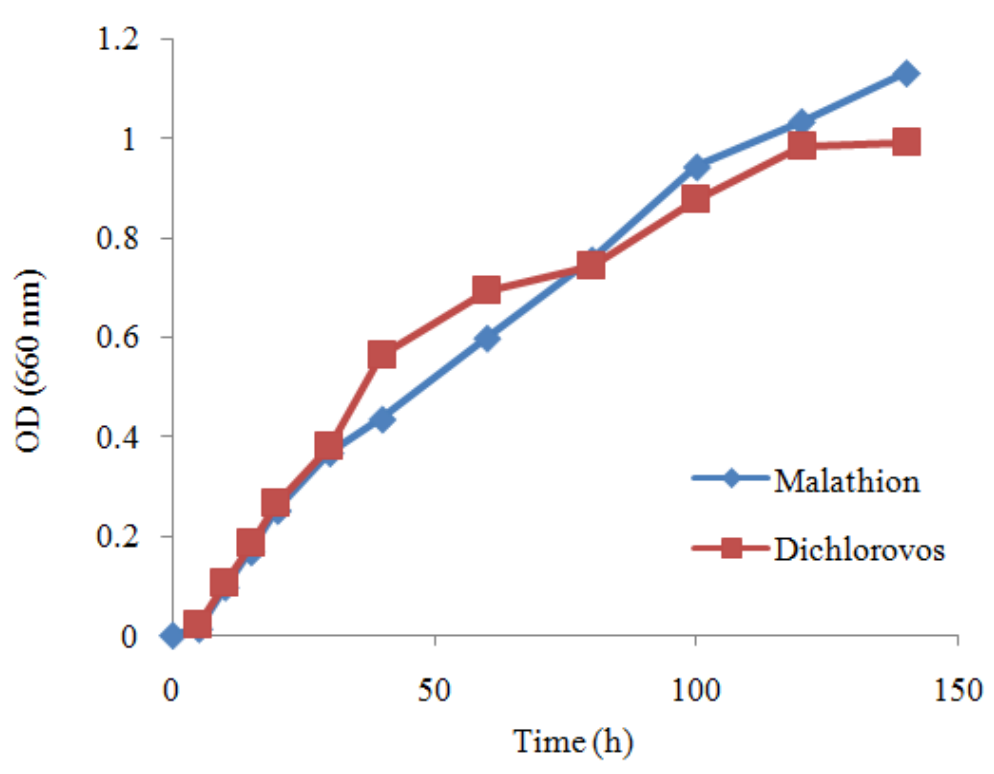

Fig. 1. Bacterial growth by Staphylococcus sp. AUG6, in mineral salt medium supplemented with Malathion and Dichlorvos as a sole carbon source during biodegradation studies

\section{Degradation Studies of Pesticide}

The all isolated bacterial colonies were pre cultured in $10 \mathrm{~mL} \mathrm{LB}$ medium and incubated $37^{\circ} \mathrm{C}$. Bacterial cultures with $1 \mathrm{OD}$ at $660 \mathrm{~nm}$ were used as inoculum. Degradation analyses were performed in $250 \mathrm{~mL}$ conical flask containing $100 \mathrm{~mL}$ of MSM supplemented with sucrose $\left(10.0 \mathrm{~g}^{\text {-lit }}\right)$ and peptone $\left(2.0 \mathrm{~g}^{\text {-lit }}\right)$. Sterilized Malathion and Dichlorvos (100 mg $\left.{ }^{- \text {lit }}\right)$ were added after autoclaving the MSM medium (Yang et al., 2006).

Media were inoculated with $5 \mathrm{~mL}^{- \text {lit }}$ biomass and incubated in the dark on an orbital shaker $(100 \mathrm{rpm})$ at $30^{\circ} \mathrm{C}$ for 7 days. Two experimental sets for cell growth were prepared in duplicate. The biomass concentration was estimated by optical density measurement in $1 \mathrm{~cm}$ cuvettes at wavelength of 660 nm using UV-Visible spectrophotometer.

\section{Production of Protein}

All the isolates were used for production of protein by using (MSM) supplemented with Sucrose 2.0, Yeast extract 3.0 containing each pesticide (Malathion, Dichlrovose) with concentration $100 \mathrm{mg} / \mathrm{lit}$ for 7 days. Cultures were centrifuged for $15 \mathrm{~min}$ at $7000 \mathrm{rpm}$ and $4^{\circ} \mathrm{C}$. The supernatants were used for the amount of total protein described by the quantitation method by Lowry et al. (1951). The Lowry Assay quantitates protein depending on measuring changes in absorbance at a wavelength of 660 $\mathrm{nm}$ when Folin reagent interacts with protein.

\section{Optimization of Physicochemical Condition}

The growth efficacy of AUG in pesticides was studied of different temperature $\left(25-50^{\circ} \mathrm{C}\right)$ and $\mathrm{pH}(5$ to 10). The optimized $\mathrm{pH} 7.0$ and temperature $30^{\circ} \mathrm{C}$ were selected to studying the various physicochemical 
parameters such as initial pesticide concentration (100$800 \mathrm{mg} / \mathrm{L}$ ), effect of $\mathrm{NaCl}$ and effect of Yeast extract on the growth pattern of AUG12.

\section{Software for Data Analysis and Bacteria Identification}

MS Excel 7 also used for the preparation of various graph. An offline software 'PIBWIN' was used for identification of the isolated bacteria http://www.tgw1916.net/bacteria_logare.html.

\section{Extraction of Enzyme and Organophosphorous Phosphatase Assay}

The cells grown in MSM broth containing $100 \mathrm{mg} / \mathrm{L}$ pesticides were harvested and pelleted by centrifugation at $12,000 \mathrm{rpm}$ for $120 \mathrm{~min}$. The supernatant was used to determine extracellular organophosphorous phosphatase activity (Wang et al., 2008). All the experiments were repeated two times. Organophosphorous phosphatase activity was measured by adding $100 \mu \mathrm{L}$ of crude enzyme to $900 \mu \mathrm{L}$ of Tris $\mathrm{HCl}$ containing $10 \mathrm{mg} / \mathrm{mL}$ p-nitrophenol phosphate and the mixture was incubated for $15 \mathrm{~min}$ at $37^{\circ} \mathrm{C}$. After that reaction was terminated by addition of 1 $\mathrm{mL}$ of $10 \%$ trichloroacetic acid and $1 \mathrm{~mL}$ of $10 \%$ sodium carbonate and the liberated yellow colored end product $\mathrm{p}$ nitrophenol was measured in a spectrophotometer at 410 $\mathrm{nm}$. One unit (U) of OPP activity is defined as the amount of enzyme liberating $1 \mathrm{lmol}$ of p-nitrophenol per minute at $37^{\circ} \mathrm{C}$ (Alvarez-Macarie et al., 1999).

\section{Results}

\section{Isolation and Identification of Pesticide Degrading Bacteria}

Six different microorganisms were isolated from the pesticide contamination Soil samples by enrichment culture method. All isolates were found to shown the ability to grow in the presence of pesticide, the strains named as AUG 6, 8, 9, 11, 12, 13 and stored in the glycerol stock for further studies.

\section{Identification of Pesticide Degrading Bacteria}

Morphological, Gram staining and biochemical test were perform with Bergey's Manual of Determinative Bacteriology and using 'PIBWIN' online software for tentative identification of the isolates. The results of gram staining and biochemical test are shown in Table 2. It was found that, the isolates AUG6, AUG8, AUG9, AUG11, AUG12 and AUG13 were Staphylococcus sp. Micrococcus $s p$. Entrobacte sp. Bordetella sp. Pseudomonas sp. and Klebsella sp. respectively (Table 2 and 3 ).

\section{Growth by the Isolates in Mineral Salt Medium (MSM)}

The degradation of Malathion and Dichlorvos perform under the aerobic condition by each strain for a period of $140 \mathrm{~h}$ in Mineral Salt Medium. Cell growth was measured by measuring OD $660 \mathrm{~nm}$ by following periodic interval. The bacterial growth increased rapidly during $10 \mathrm{~h}$ of incubation. The results for the isolates Pseudomonas sp. AUG12 showed best growth patterns for Malathion and Dichlorvos within 140 h (Fig. 1-6).

\section{Plate Assay for Malathion and Dichlorvos}

Plate assays revealed that Pseudomonas sp. Staphylococcus sp. Entrobacte sp. and Klebsella sp. had a higher tolerance to Malathion (1700-1900 mg/L) and the least tolerance was noted for Micrococcus (1200 $\mathrm{mg} / \mathrm{L})$ shown in Fig. 7. Similarly Micrococcus $s p$. Entrobacte sp. Pseudomonas sp. had a higher tolerance to Dicholorovos $(1500-1600 \mathrm{mg} / \mathrm{L})$ and the least tolerance was noted for Staphylococcus sp. Bordetella sp. and Klebsella sp. (1300 mg/L).

\section{Total Protein Concentration}

Total protein content was measured in all supernatant of isolates. According to the Lowry Assay, the protein concentration for the AUG12 was the highest, while AUG8 was the lowest (Fig. 8).

\section{Effect of Temperature}

Bacteria required optimum temperature for growth which is important for degradation of pesticides. The isolate Pseudomonas sp. AUG12 showed maximum growth at $27^{\circ} \mathrm{C}, 37^{\circ} \mathrm{C}$ and $40^{\circ} \mathrm{C}$ and almost no growth was found at $50^{\circ} \mathrm{C}$. This might be due to thermal inactivation of protein and enzyme activity. The bacteria showed rapid growth pattern that is within $22 \mathrm{hr}$ was measured at $30^{\circ} \mathrm{C}$ (Fig. 9).

\section{Effect of $p H$}

Bacteria required optimum $\mathrm{pH}$ for maximum growth which is important for degradation of pesticides. The isolate Pseudomonas sp. AUG12 showed maximum growth at $\mathrm{pH}$ 7,8 and almost no growth was found at $\mathrm{pH} \mathrm{5,6.} \mathrm{This} \mathrm{might}$ be due to denaturation of protein and enzyme activity. The bacteria showed rapid growth pattern that is within $40 \mathrm{~h}$ was absorbed at pH 7 (Fig. 10).

\section{Effect Initial Pesticide Concentration}

The growth performance of the Pseudomonas sp. AUG12 strain was studies by increasing initial dye concentration (100-800 mg/L). The growth activity was lower at $500 \mathrm{mg} / \mathrm{lit}$ and above. It could effective growth up to $100 \mathrm{mg} / \mathrm{lit}$ of Malathion and Dicholorovos within $100 \mathrm{hr}$ and decreased, when pesticide concentration increase to $800 \mathrm{mg} /$ lit (Fig. 11).

\section{Effect of Carbon Source}

Effect of different carbon source such as starch, lactose, sucrose, glucose and maltose were evaluated on growth of Pseudomonas sp. AUG12. 
Table 2. Colony characteristics, Morphological characteristics of six different Malathion and Dichlorvos degrading isolates grown on nutrient agar at $30^{\circ} \mathrm{C}$ for $24 \mathrm{~h}$ (S, small; M, Moderate; DW, Dirty White; LY, Light Yellow; LC, Light Cream; NP, No Pigment; TL, Translucent; OP, Opaque)

\begin{tabular}{|c|c|c|c|c|c|c|c|c|}
\hline \multirow[b]{2}{*}{ Isolates } & \multicolumn{8}{|c|}{ Colony characterization } \\
\hline & Size & Shape & Margin & Elevation & Surface texture & Consistency & Opacity & Pigmentation \\
\hline AUG-6 & $\mathrm{M}$ & Round & Entire & Convex & Smooth & Gummy & OP & LY \\
\hline AUG-8 & $\mathrm{S}$ & Irregular & Lobed & Low convex & Smooth & watery & $\mathrm{TL}$ & NP \\
\hline AUG-9 & M & Irregular & Uneven & Low convex & Smooth & Gummy & OP & NP \\
\hline AUG-11 & M & Round & Even & Convex & Rough & Gummy & OP & DW \\
\hline AUG-12 & $\mathrm{S}$ & Uneven & Entire & Flat & Smooth & Gummy & OP & LY \\
\hline AUG-13 & $\mathrm{M}$ & Irregular & Lobed & Flat & Rough & Gummy & OP & $\mathrm{LC}$ \\
\hline
\end{tabular}

Table 3. Biochemical characteristics of six different Malathion and Dichlorvos degrading isolates grown on nutrient agar at $30^{\circ} \mathrm{C}$ for $24 \mathrm{~h}$ (R, Red; Y, Yellow)

\begin{tabular}{|c|c|c|c|c|c|c|}
\hline Biochemical Chlaracterization & AUG6 & AUG8 & AUG9 & AUG11 & AUG12 & AUG13 \\
\hline Indole production & - & - & + & - & - & - \\
\hline Urea hydrolysis & - & - & - & - & - & - \\
\hline Catalase & + & + & + & + & + & + \\
\hline Gelatin hydrolysis & - & - & - & - & - & - \\
\hline Citrate utilization & - & + & + & + & + & + \\
\hline Starch hydrolysis & - & + & + & - & - & + \\
\hline Motility test & + & - & + & + & + & - \\
\hline MR test & - & - & - & - & - & - \\
\hline VP test & - & - & - & + & - & - \\
\hline Arginine hydrolysis & - & - & - & - & - & - \\
\hline Casein utilization & + & - & - & - & - & - \\
\hline TSI & $\mathrm{Y}$ & $\mathrm{R} / \mathrm{Y}$ & $\mathrm{R} / \mathrm{Y}$ & $\mathrm{Y}$ & $\mathrm{R} / \mathrm{Y}$ & $\mathrm{R} / \mathrm{Y}$ \\
\hline Sugar test & + & + & + & + & + & + \\
\hline $\mathrm{H}_{2} \mathrm{~S}$ test & - & - & - & - & - & - \\
\hline $\mathrm{Co}_{2}$ test & - & - & - & - & - & - \\
\hline Gram staining & + & - & - & - & - & - \\
\hline Identified cultures & Staphylococcus sp. & Micrococcus sp. & Entrobacte sp. & Bordetella sp. & Pseudomonas sp. & Klebsella sp. \\
\hline
\end{tabular}

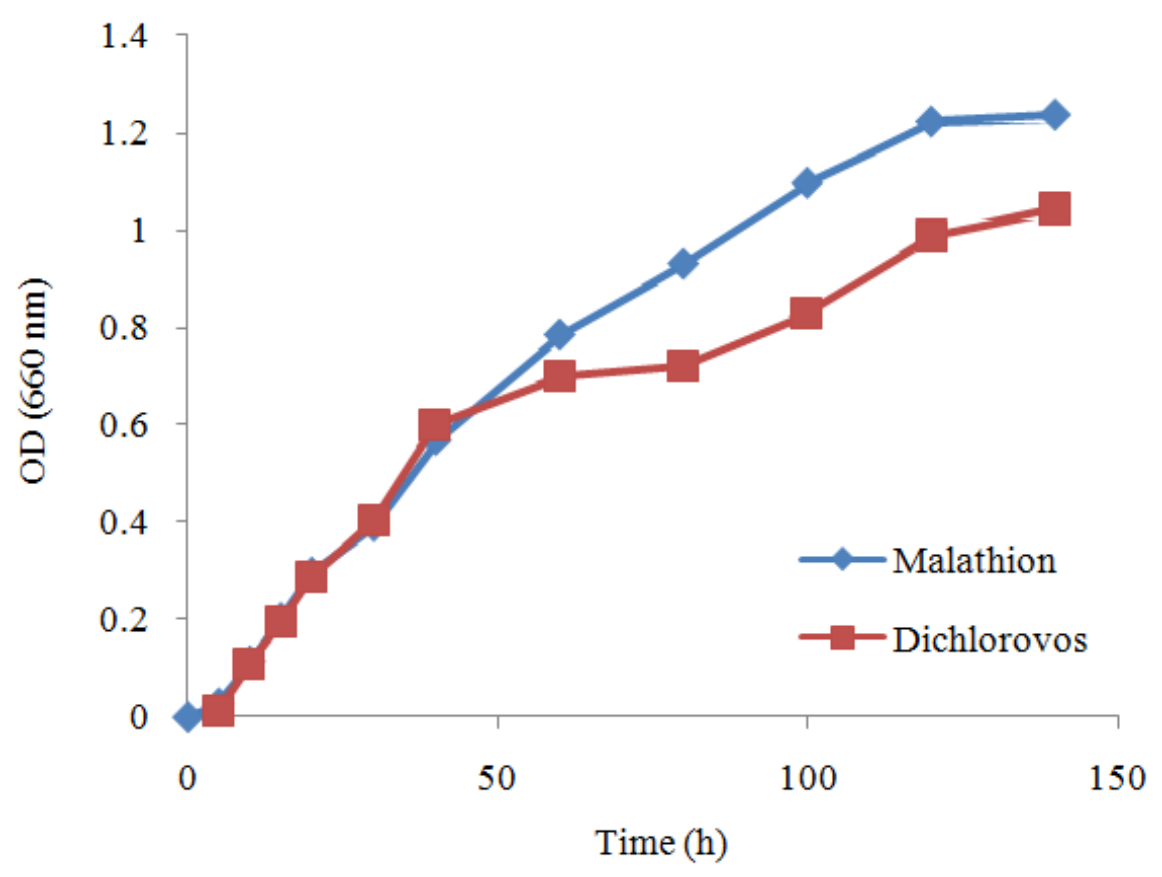

Fig. 2. Bacterial growth by Micrococcus sp. AUG8, in mineral salt medium supplemented with Malathion and Dichlorvos as a sole carbon source during biodegradation studies 


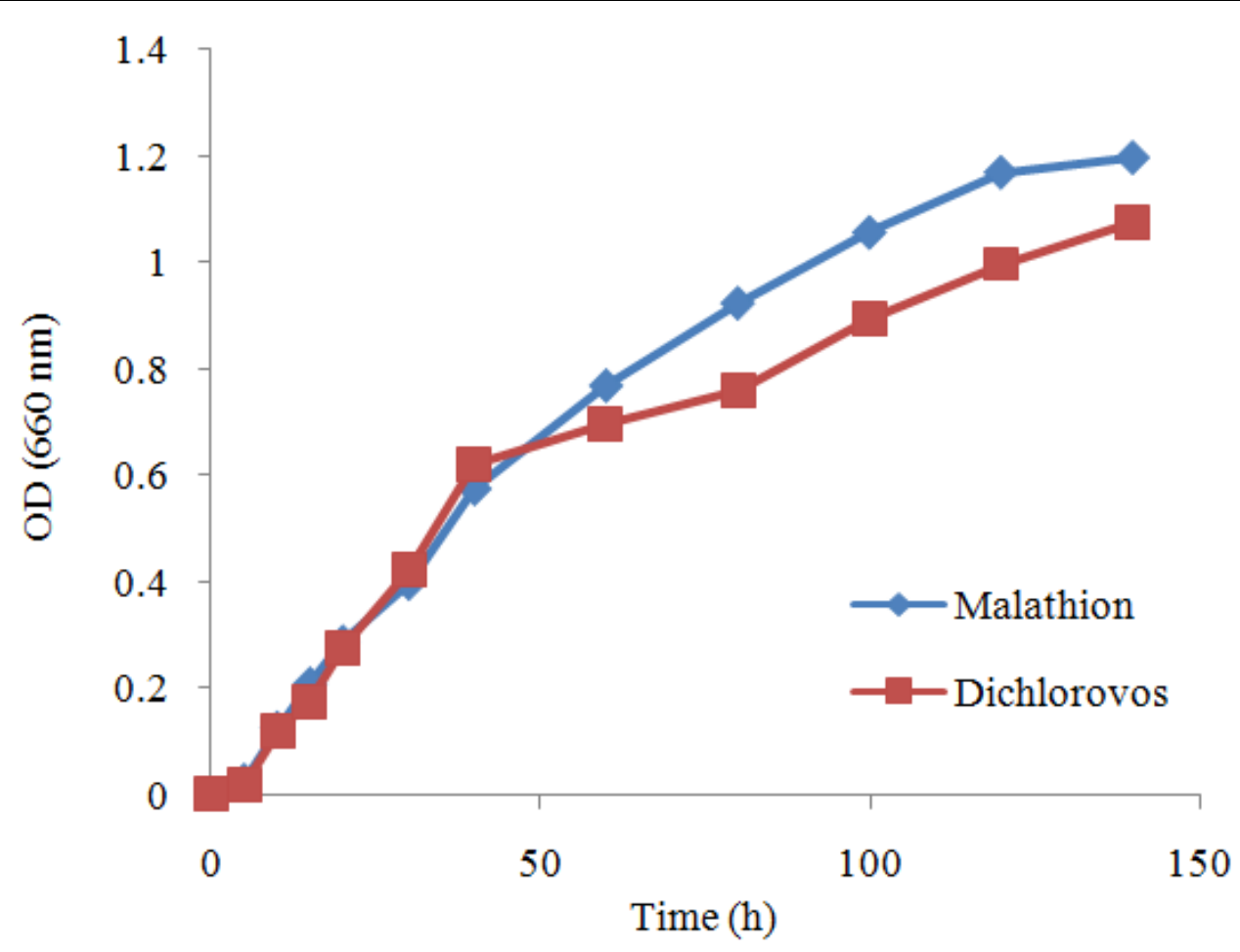

Fig. 3. Bacterial growth by Entrobacte sp. AUG9, in mineral salt medium supplemented with Malathion and Dichlorvos as a sole carbon source during biodegradation studies

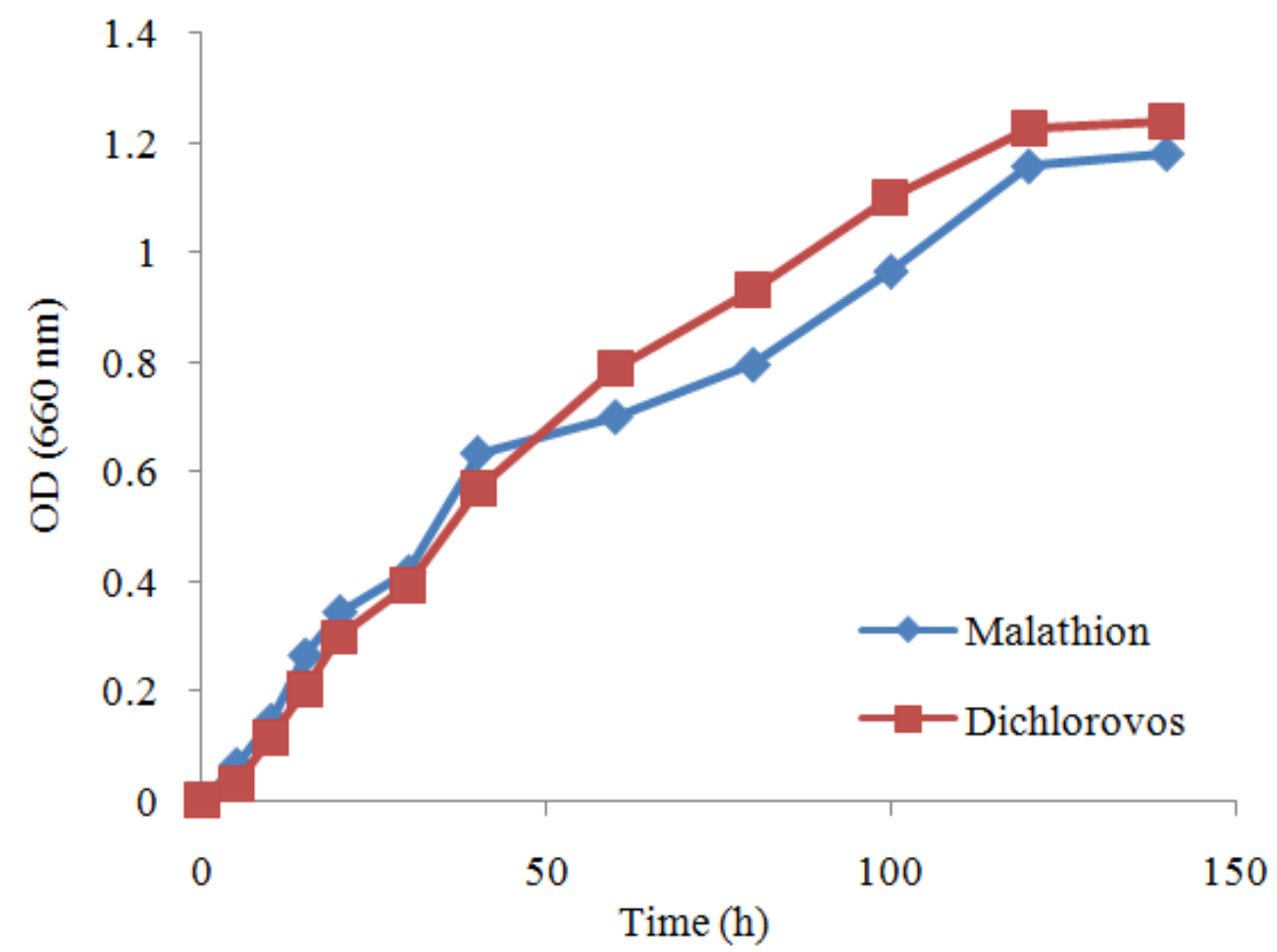

Fig. 4. Bacterial growth by Bordetella sp. AUG11, in mineral salt medium supplemented with Malathion and Dichlorvos as a sole carbon source during biodegradation studies 


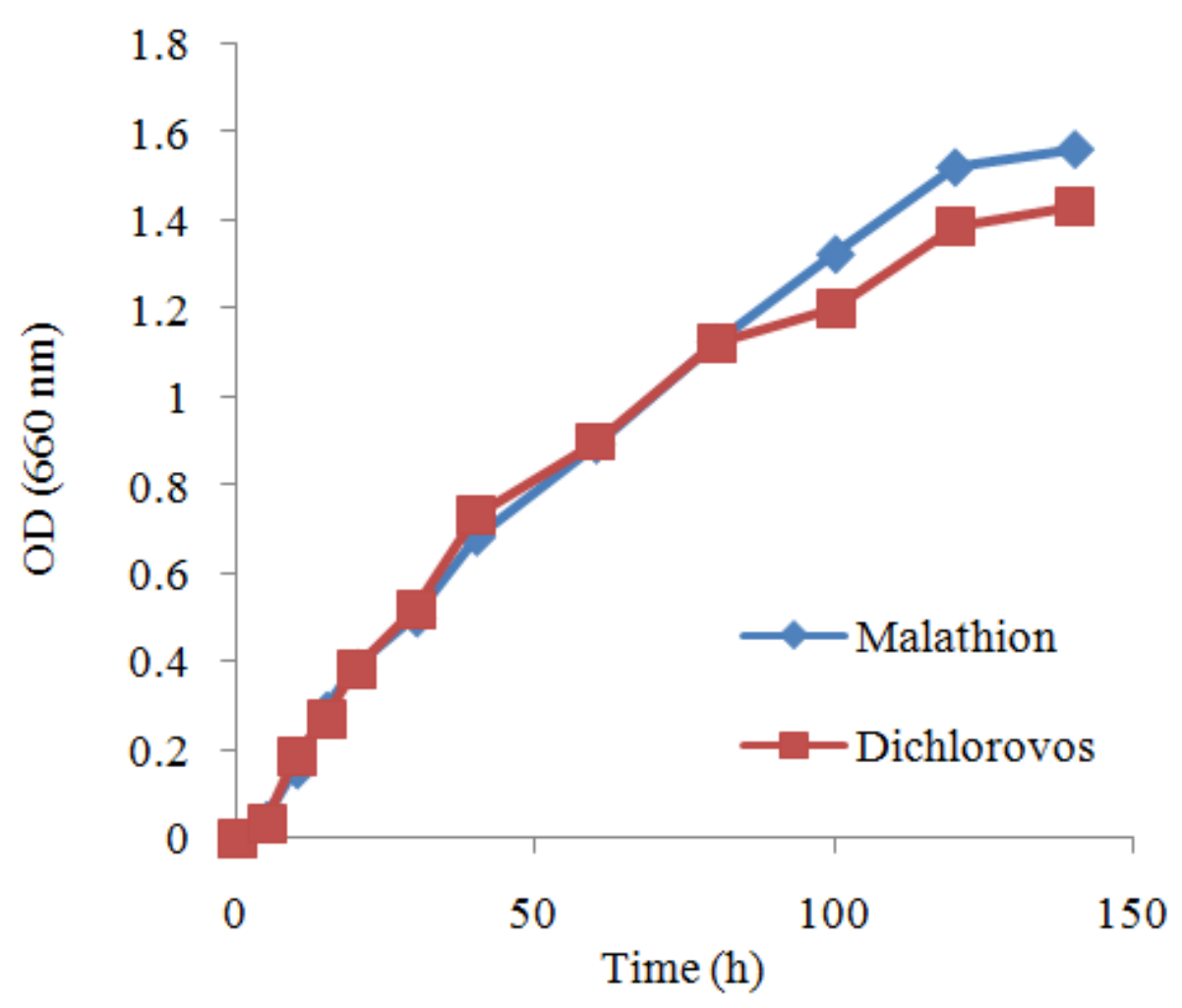

Fig. 5. Bacterial growth by Pseudomonas sp. AUG12, in mineral salt medium supplemented with Malathion and Dichlorvos as a sole carbon source during biodegradation studies

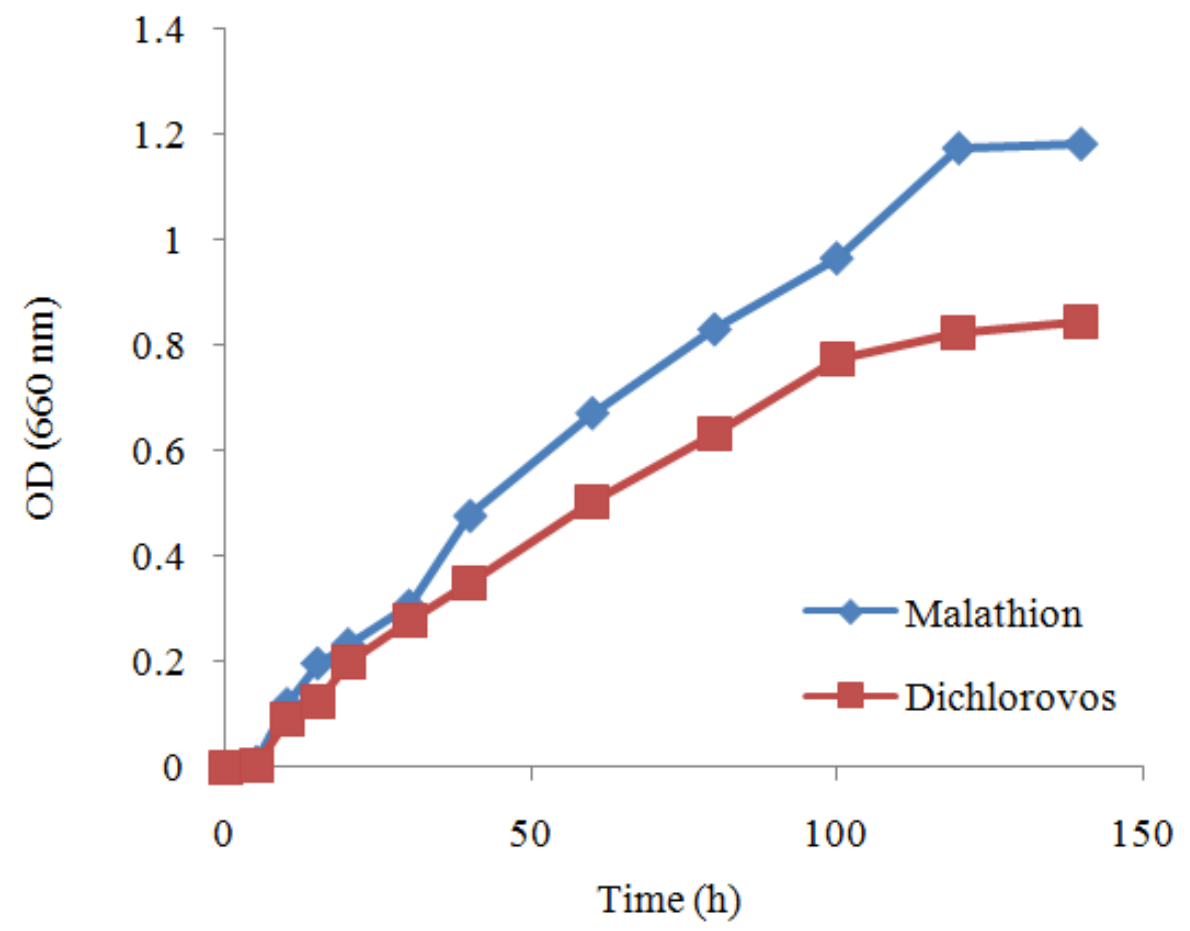

Fig. 6. Bacterial growth by Klebsella sp. AUG13, in mineral salt medium supplemented with Malathion and Dichlorvos as a sole carbon source during biodegradation studies 


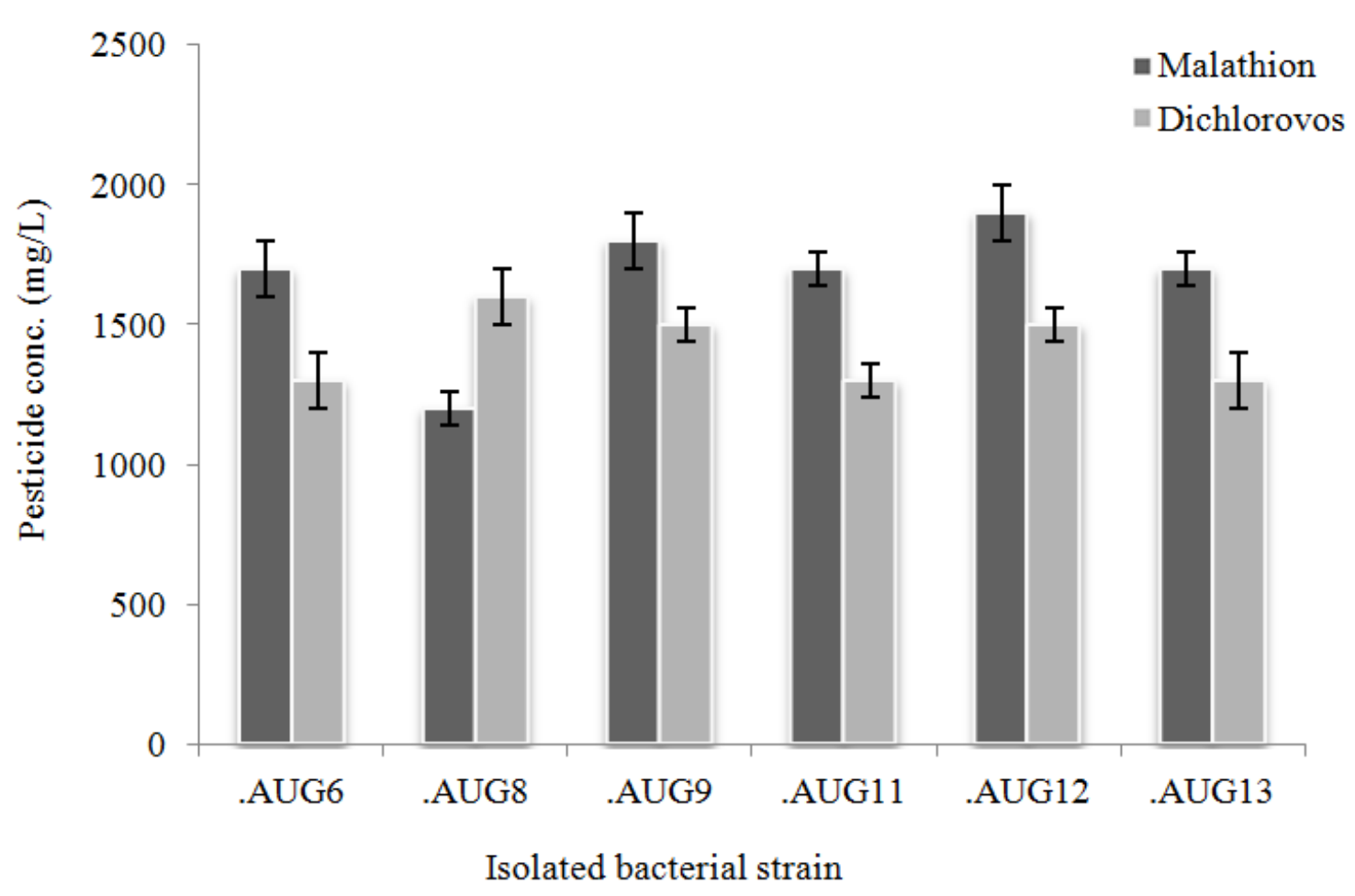

Fig. 7. Bar graph showing growth of the isolated bacterial strains on Minimal Salt (MS) agar plates supplemented with various concentrations (100-2,000 mg/L) of Malathion and Dichlorvos

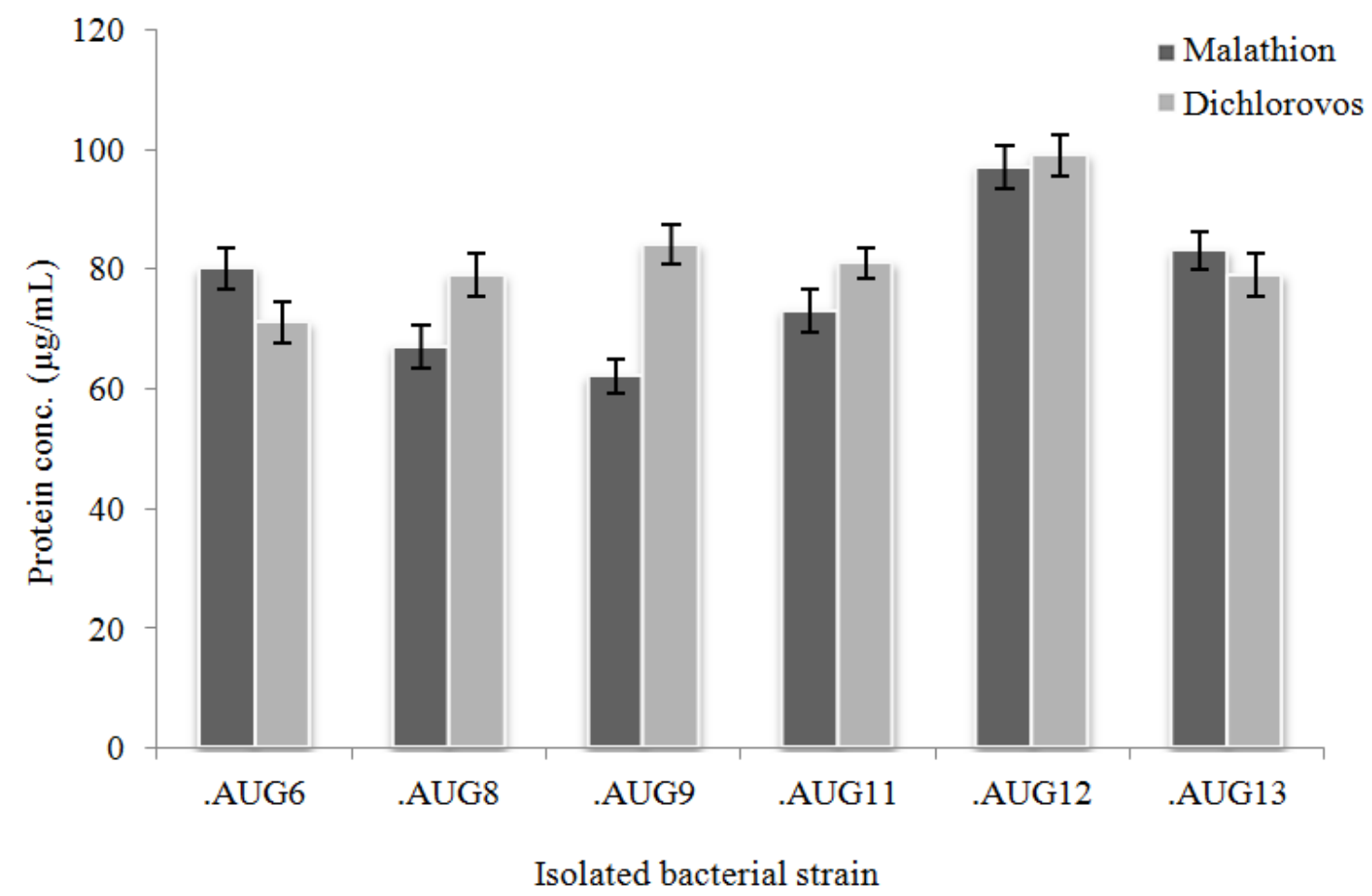

Fig. 8. Bar graph showing concentration of total protein produced by isolated bacterial strains on Minimal Salt (MS) agar plates supplemented with various concentrations $(100 \mathrm{mg} / \mathrm{Lit})$ of Malathion and Dichlorvos 


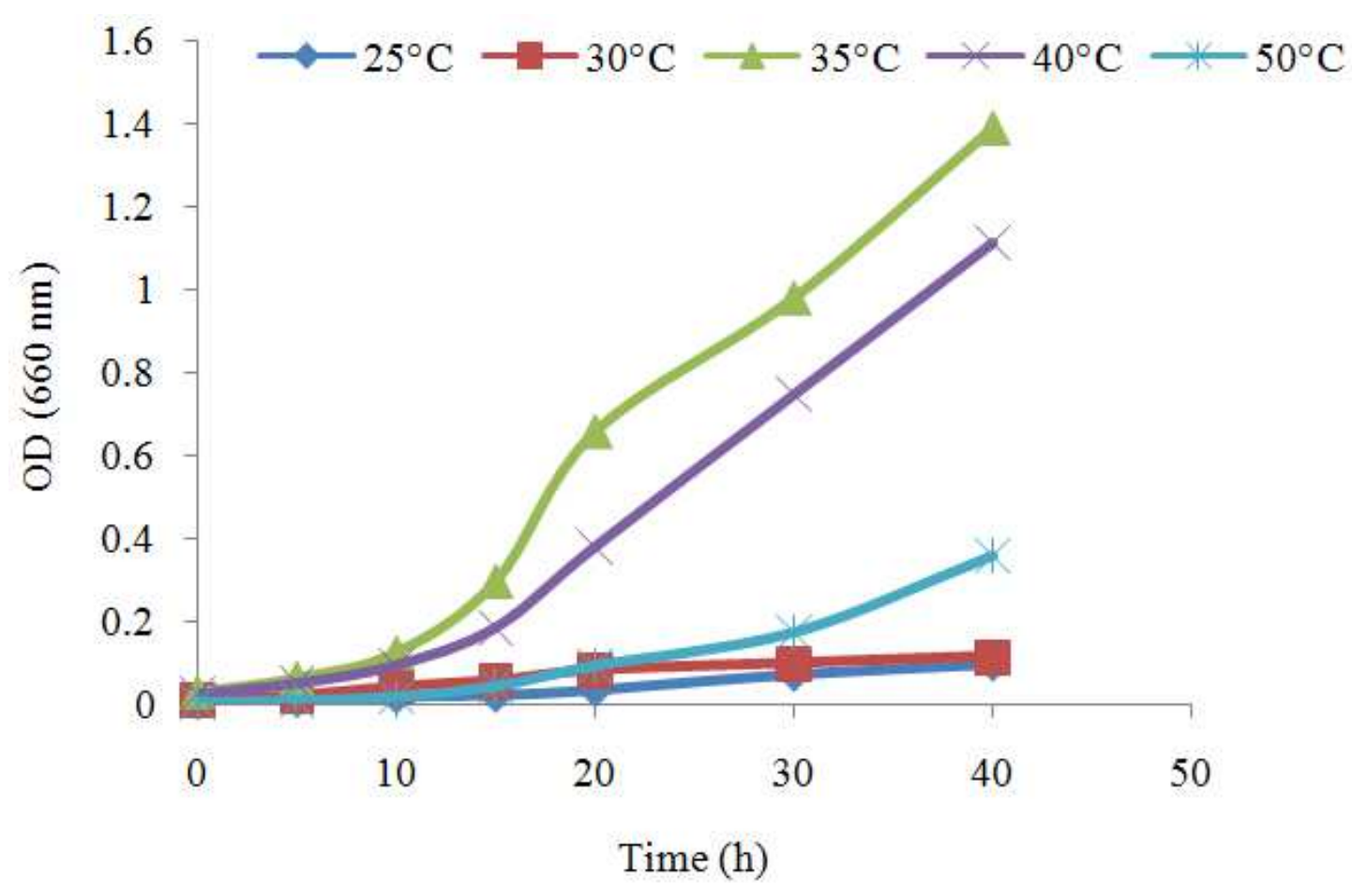

Fig. 9. Effect of temperature on the growth of Pseudomonas sp. AUG12 bacteria in Minimal Salt broth containing Malathion

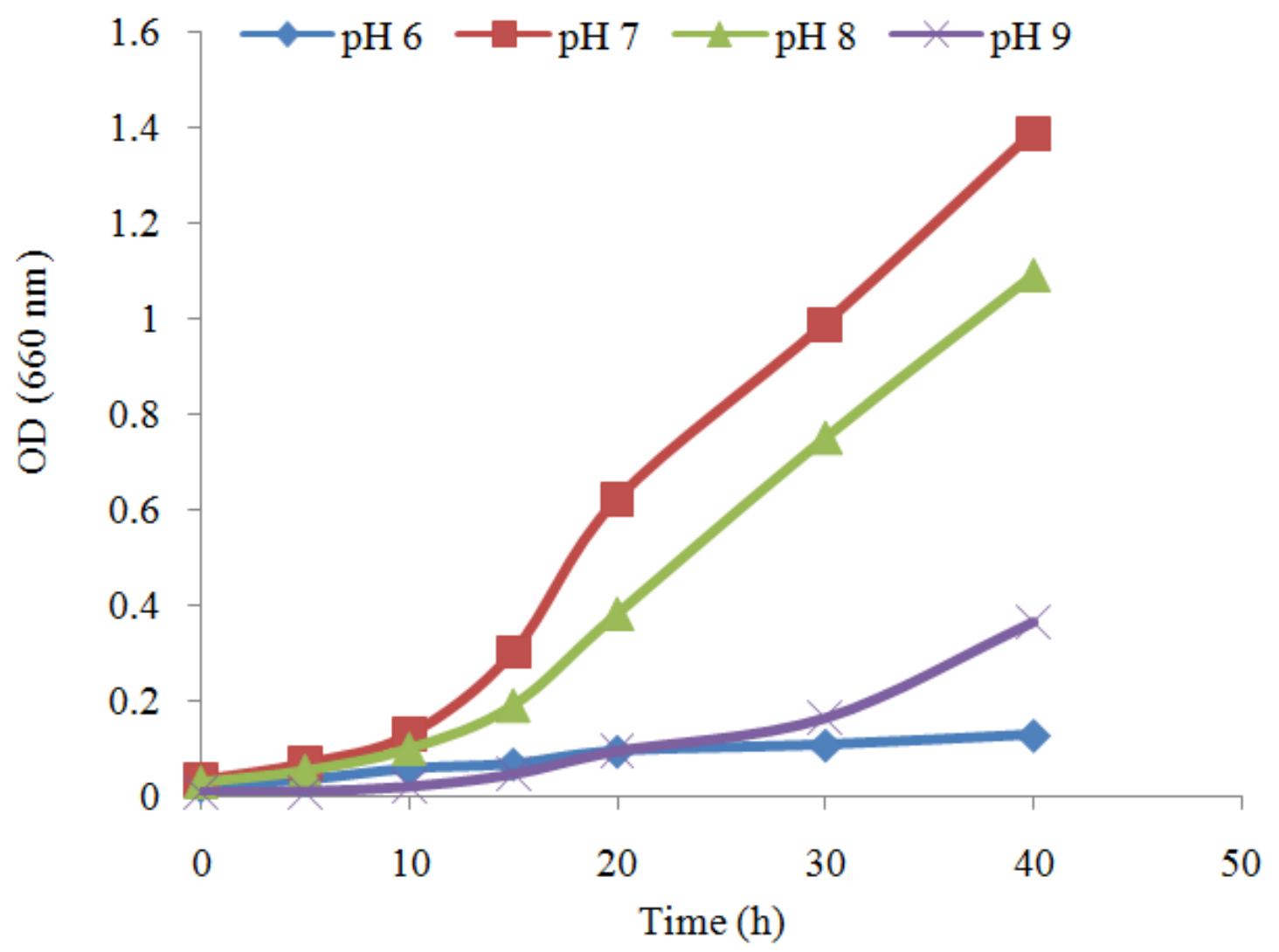

Fig. 10. Effect of $\mathrm{pH}$ on the growth of Pseudomonas sp. AUG12 bacteria in Minimal Salt broth containing Malathion 


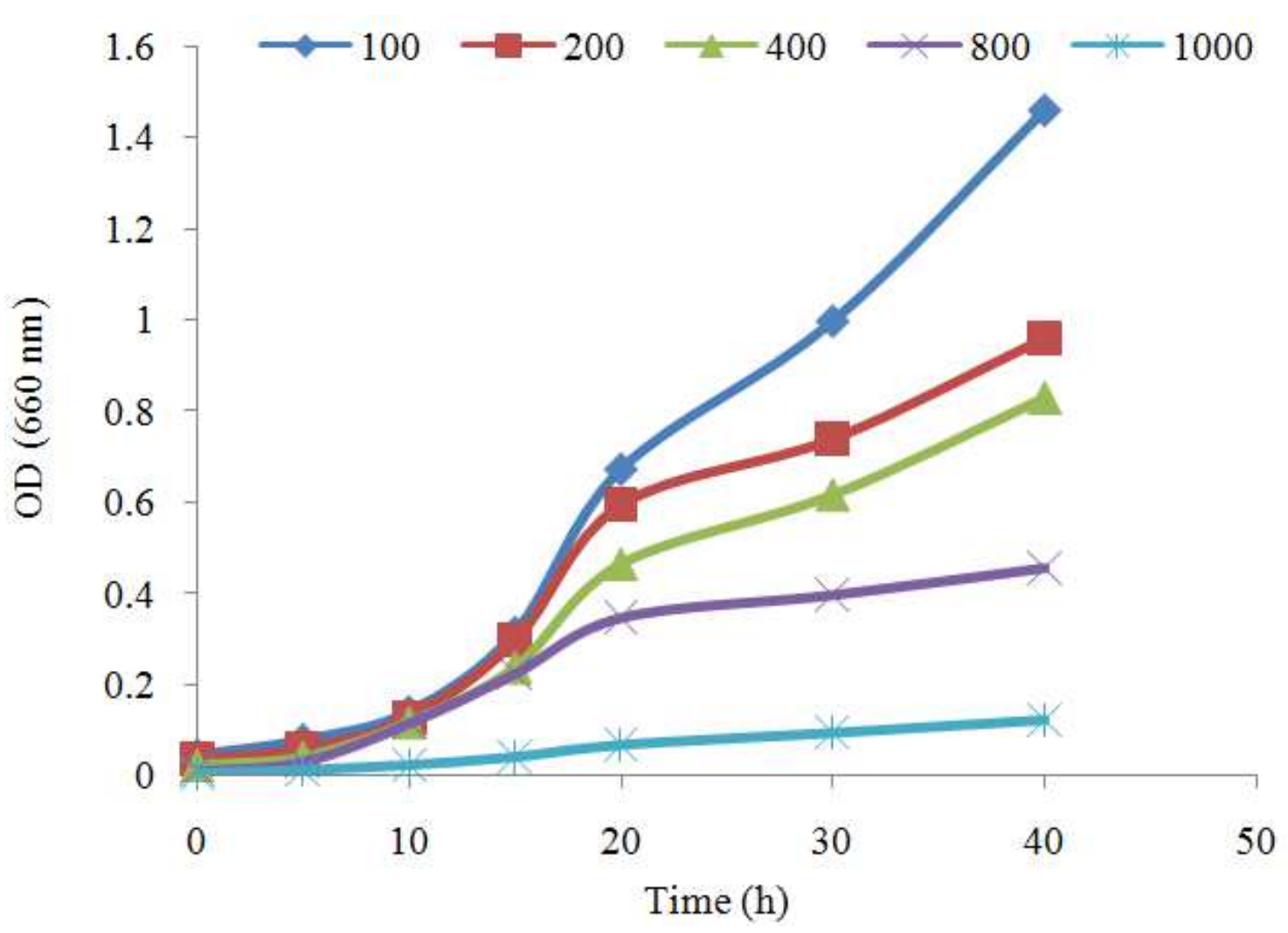

Fig. 11. Effect of initial pesticide concentration on the growth of Pseudomonas sp. AUG12 bacteria in Minimal Salt broth containing Malathion

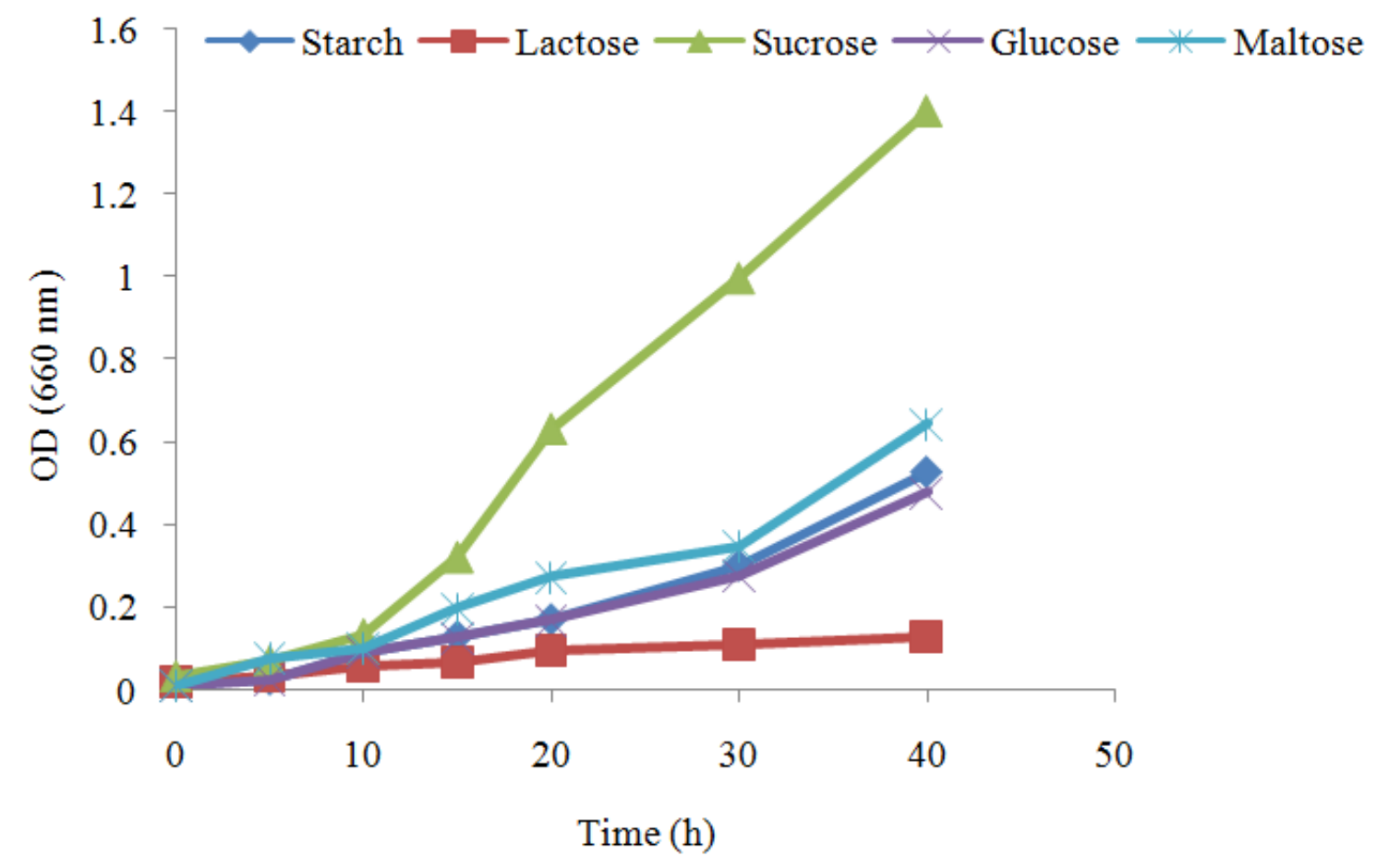

Fig. 12. Effect of various Carbon source on the growth of Pseudomonas sp. AUG12 bacteria in Minimal Salt broth containing Malathion 


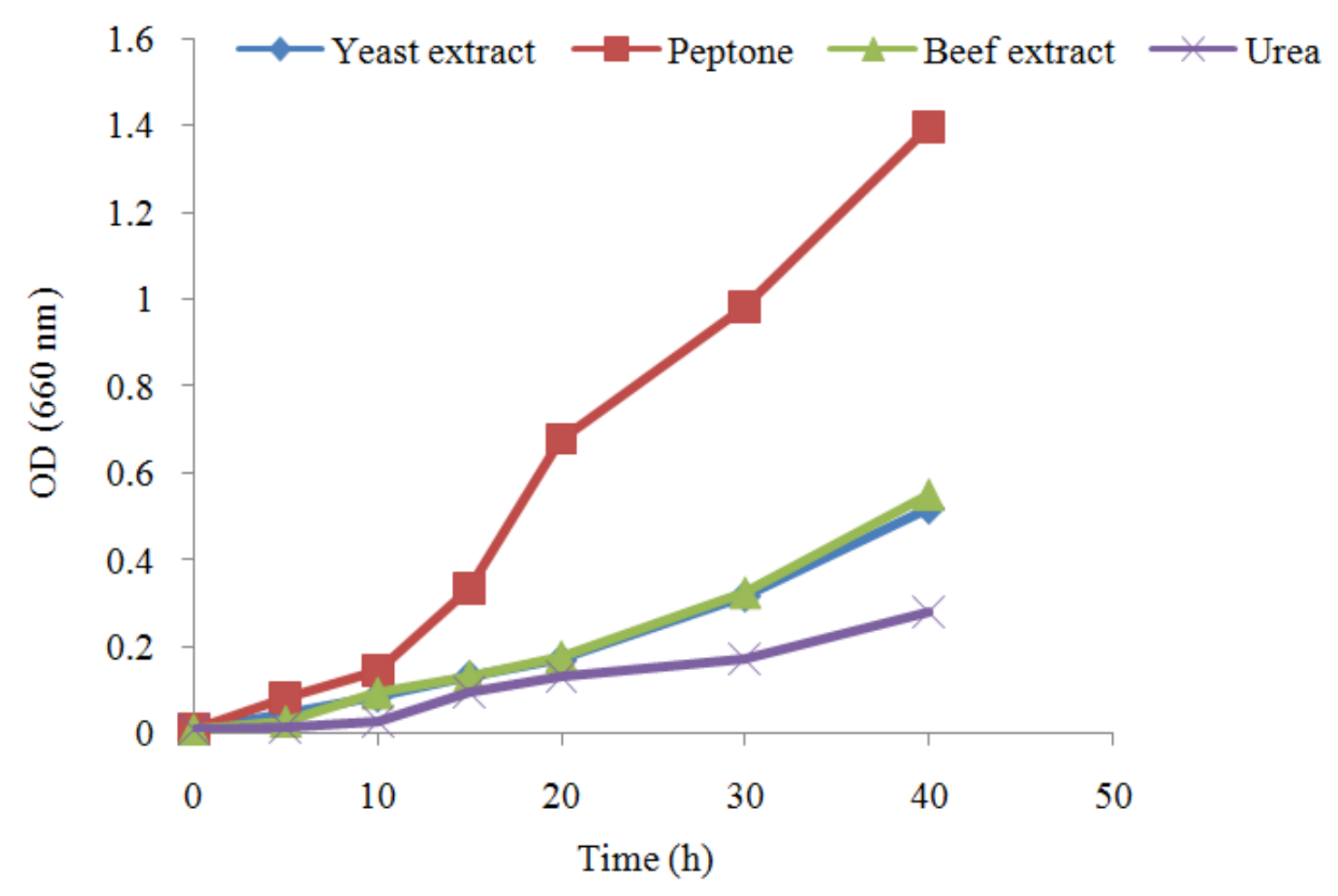

Fig. 13. Effect of various Nitrogen source on the growth of Pseudomonas sp. AUG12 bacteria in Minimal Salt broth containing Malathion

It was found that the bacterial strain showed maximum growth in the presence of sucrose and moderate growth was shown in presence of starch, maltose where as negligible growth in the presence of lactose (Fig. 12).

\section{Effect of Nitrogen Source}

Different type of nitrogen source such as yeast extract, peptone, urea and beef extract are used to study the growth rate of Pseudomonas sp. AUG12. The results showed negligible growth of in the presence of urea, where as moderate growth activity was shown in the presence of yeast extract and beef extract and maximum growth was reported in the presence of peptone (Fig. 13).

\section{Organophosphorous Phosphatase (OPP) Assay}

The enzyme organophosphorous phosphatase determined by the OPP assay was found to be present in the intracellular fractions of the six selected isolates. The extracellular OPP activity was $0.0079 \mathrm{U}$ in Pseudomonas sp. AUG12.

\section{Discussion}

To increase the agricultural yield insecticides plays an important role, but only less than $1 \%$ of the pesticides are enough to kill the pests, remaining pesticides enter into the ground and surface water and causes environmental pollution and affect human health also (Battaglin and Fairchild, 2002). Thus some of the persistent pesticides were banned and some are modified without damaging to the environment. However, organophosphates are creating a lot of human health problems (Sogorb et al., 2004). Different kinds of bacteria present in soil are capable of degrading many persistent pesticides (Ramanathan and Lalithakumari, 1999; El-Deeb et al., 2000; Bhadbhade et al., 2002; Chen et al., 2002).

A total of six isolates were used in this study which were isolated from Gwalior region of Madhya Pradesh. The tentative identification of isolates was done by various biochemical tests. These isolates were tested for the pesticides tolerance against Malathion and Dichlorvos. The tolerant efficiency of isolates was tested by cell plat efficacy test. The growth curve of all Six isolates were measured by spectrophotometry analysis. The total protein content also measured at the end of degradation. The most tolerant strains were selected for the optimization of physicochemical parameter for maximum growth. The maximum growth rate of Pseudomonas sp. AUG12 was recorded at $\mathrm{pH} 7$ followed by $\mathrm{pH} 7$ at $30^{\circ} \mathrm{C}$. The growth of bacteria was maximum in the presence of sucrose and peptone as a carbon and nitrogen source respectively. The growth of Pseudomonas sp. AUG12 was 
decreased by increasing the concentration of pesticide. Interestingly, the extracellular OPP activity of Pseudomonas sp. AUG12 was very high.

\section{Conclusion}

Six bacterial isolates belonging to Staphylococcus, Micrococcus, Entrobacte, Bordetella, Pseudomonas and Klebsella genera were isolated and identified, which had efficient degradation capability of the organophosphorus pesticide Malathion and Dichlorvos. Addition of Sucrose and peptone enhanced the growth of the isolated strain Pseudomonas sp. AUG12. Results of the good growth of isolates indicated that apart from chemical processes microbial degradation is considered to be one of the main mechanisms of Malathion and Dichlorvos dissipation in water. Moreover, obtained results have implications for the development of a bioremediation strategy of Malathion and Dichlorvos polluted water.

\section{Acknowledgement}

The authors are grateful to Director, Madhav Institute of Technology and Science, Gwalior, MP, India for providing necessary facilities and encouragement. The authors are also thankful to all faculty members of the Institute of Department of Biotechnology, Madhav Institute of Technology and Science, Gwalior, MP, India for their generous support during the course of experimental work and manuscript preparation.

\section{Author Contributions}

Hotam Singh Chaudhary: Development of research idea, supervising research work, analysis of whole data, writing draft of whole manuscript and final approval of manuscript.

Soni Yadav: Isolation and Characterization of Organophosphate Pesticides Degrading Bacteria, compiling and analysis of whole data, reading draft and final approval of manuscript.

Sitansu Kumar Verma: Helping in lab work, compiling and analysis of whole data, reading draft, correcting and final approval of manuscript.

\section{Ethics}

This article is original and contains unpublished material. The corresponding author confirms that all of the other authors have read and approved the manuscript and no ethical issues involved

\section{References}

Abo-Amer, S. and E. Aly, 2011. Biodegradation of diazinon by serratia marcescens di101 and its use in bioremediation of contaminated environment. J. Microbiol. Biotechnol., 21: 71-80.
Ahn, K.C., S.J. Gee, K.J. Kim, P.A. Aronov and H. Vega, 2011. Immunochemical analysis of 3phenoxybenzoic acid, a biomarker of forestry worker exposure to pyrethroid insecticides. Analytical Bioanalytical Chemistry, 401: 1285-1293.

DOI: $10.1007 / \mathrm{s} 00216-011-5184-\mathrm{z}$

Alvarez-Macarie, E., V. Augier-Magro and J. Baratti, 1999. Characterization of a thermostable esterase activity from the moderate thermophile Bacillus licheniformis. Bioscience Biotechnology Biochemistry, 63: 1865-1870.

Aruna, M., R.M. Raju and K.N. Reddy, 2014. Validation of multi residue method for organo phosphate pesticides in water and sediments by gas chromatography with pulsated flame photometric detector. Res. J. Pharm. Biol. Chem. Sci., 5: 488-497.

Atit, W.A., K.K. Ghaima, S.A. Ali and M.M. Mohammed, 2013. Study the growth kinetics of Pseudomonas aeruginosa degrading some pesticides which isolated from cultivated soil. Iraq J. Market Res. Consumer Protect., 5: 157-167.

Basarslan, S.K., H. Alp, S. Senol, O. Evliyaoglu and U. Ozkan, 2014. Is intralipid fat emulsion a promising therapeutic strategy on neurotoxicity induced by malathion in rats? Eur. Review Med. Pharmacolo. Sci., 18: 471-476. PMID: 24610612

Battaglin, W. and J. Fairchild, 2002. Potential toxicity of pesticides measured in midwestern streams to aquatic organisms. Water Sci. Technol., 45: 95-102.

Bhadbhade, B.J., S.S. Sarnaik and P.P. Kanekar, 2002. Bioremediation of an industrial effluent containing monocrotophos. Current Microbiol., 45: 346-349. DOI: $10.1007 / \mathrm{s} 00284-002-3681-1$

Buchanan, R. and N. Gibbons, 1984. Bergey's Manual of Determinative Bacteriology. 9th Edn., Baltimore, USA.: Williums and Wilkins Co.

Chen, S., C. Liu, C. Peng, H. Liu and M. Hu, 2012. Biodegradation of chlorpyrifos and its hydrolysis product 3,5,6-trichloro-2-pyridinol by a new fungal strain Cladosporium cladosporioides Hu-01. PloS One, 7: 47205. DOI: 10.1371/journal.pone.0047205

Chen, Y., X. Zhang, H. Liu, Y. Wang and A. Xia, 2002. Study on Pseudomonas sp. WBC-3 capable of complete degradation of methylparathion. Wei Sheng Wu Xue Bao., 42: 490-497. PMID: 12557558

Cowan, S.T., 1974. Manual for the Identification of Medical Bacteria. 2nd Edn., Cambridge University Press, London, pp: 238.

Cycon, M., M. Wojcik and Z. Piotrowska-Seget, 2009. Biodegradation of the organophosphorus insecticide diazinon by Serratia sp. and pseudomonas sp. and their use in bioremediation of contaminated soil. Chemosphere, 76: 494-501.

DOI: $10.1016 /$ j.chemosphere.2009.03.023 
Eddleston, M., N.A. Buckley, P. Eyer and A.H. Dawson, 2008. Management of acute organophosphorus pesticide poisoning. US Nat. Library Med., 371: 597-607. PMID: 17706760

El-Deeb, B.A., S.M. Soltan, A.M. Ali and K.A. Ali, 2000. Detoxication of the herbicide diuron by Pseudomonas sp. Folia Microbiologica, 45: 211-216.

DOI: 10.1007/BF02908946

Goda, S.K., I.E. Elsayed, T.A. Khodair, W. El-Sayed and M.E. Mohamed, 2010. "Screening for and isolation and identification of malathion-degrading bacteria: cloning and sequencing a gene that potentially encodes the malathion-degrading enzyme, carboxylestrase in soil bacteria. Biodegradation, 21: 903-913.

DOI: $10.1007 / \mathrm{s} 10532-010-9350-3$

Gunther, A.F. and J.D. Gunther, 1973. Residues of Pesticides and Other Contaminants in the Total Environment. Residue Reviews, 1st Edn., Springer, New York, ISBN-10: 978-0-387-05864-1

Hamer, G., 2010. Methanotrophy: From the environment to industry and back. Chem. Eng. J., 160: 391-397. DOI: $10.1016 /$ j.cej.2010.04.008

Jamaluddin, H., D.M. Zaki and Z. Ibrahim, 2012. Isolation of metal tolerant bacteria from polluted wastewater. Pertanika J. Trop. Agric. Sci., 35: 647-662.

Lederberg, J. and E.M. Lederberg, 1952. Replica plating and indirect selection of bacterial mutants. J. Bacteriol, 63: 399-406.

Liu, F.Y., M.Z. Hong, D.M. Liu and Y.W. Li, 2007. Biodegradation of methyl parathion by acinetobacter radioresistens USTB-04. J. Environ. Sci., 19: 1257-1260.

DOI: $10.1016 /$ S1001-0742(07)60205-8

Lowry, O.H., N.J. Rosebrough, A.L. Farr and R.J. Randall, 1951. Protein measurement with the folin phenol reagent J. Biol. Chem., 193: 265-275. PMID: 14907713

McCoy, M.R., Z. Yang, X. Fu, K.C. Ahn and S.J. Gee, 2012. Monitoring of total type II pyrethroid pesticides in citrus oils and water by converting to a common product 3-phenoxybenzoic acid. J. Agric. Food Chem., 60: 5065-5070. DOI: $10.1021 /$ jf2051653

Qi, X.J., M.L. Zheng, C.H. Wu, G.Q. Wang and C. Feng, 2012. Urinary pyrethroid metabolites among pregnant women in an agricultural area of the province of Jiangsu, China. Int. J. Hygiene Environ. Health, 215: 487-495.

DOI: $10.1016 / \mathrm{j}$. ijheh.2011.12.003
Ramanathan, M.P. and D. Lalithakumari. 1999. Complete Mineralization of methylparathion by Pseudomonas sp. A3. Appl. Biochem. Biotechn., 80: 1-12. DOI: 10.1385/ABAB:80:1:1

Shafiani, S. and A. Malik, 2003. Tolerance of pesticides and antibiotic resistance in bacteria isolated from wastewater-irrigated soil. World J. Microbio. Biotechn., 19: 897-901. DOI: 10.1023/B:WIBI.0000007290.94694.4f

Singh, D.P., J.I.S. Khattar, J. Nadda, Y. Singh and A. Garg et al., 2011. Chlorpyrifos degradation by the cyanobacterium Synechocystis sp. strain PUPCCC 64. Environ. Sci. Pollut. Res. Int., 18: 1351-1359. DOI: $10.1007 / \mathrm{s} 11356-011-0472-x$

Sogorb, M.A, E. Vilanova and V. Carrer, 2004. Future applications of phosphotriesterases in the prophylaxis and treatment of organophosporus insecticide and nerve agent poisonings. Toxicol. Lett., 151: 219-233.

DOI: 10.1016/j.toxlet.2004.01.022

Surekha, R., K.V. Lakshmi, P. Suvarnalatha, R.J. Madhuri and S. Aruna, et al., 2008. Isolation and characterization of a chlorpyrifos-degrading bacterium from agricultural soil and its growth response. Afr. J. Microbiol. Res., 2: 26-31.

Wang, J.F., M.H. Gao, N.F. Wu and C.P. Pan, 2008. The degradation effects of a Pseudomonas hydrolase OPHC2 to organophosphorus insecticides. Phosphorus Sulfur Silicon Related Elements, 183: 804-810. DOI: 10.1080/10426500701808234

Yang, C., X. Liu, X. Guo and C. Qiao, 2006. Cloning of mpd gene from a chlorpyrifos-degrading bacterium and use of this strain in bioremediation of contaminated soil. FEMS Microbiol. Lett., 265: 118-125. DOI: 10.1111/j.1574-6968.2006.00478.x

Yonar, S.M., M. Ural, S. Silici and M.E. Yonar, 2014. Malathion-induced changes in the haematological profile, the immune response and the oxidative/antioxidant status of Cyprinus carpio carpio: Protective role of propolis. Ecotoxicol. Environ. Safety, 102: 202-209. DOI: $10.1016 /$ j.ecoenv.2014.01.007 